\title{
ANALISIS FAKTOR-FAKTOR YANG MEMPENGARUHI TINGKAT PENGUNGKAPAN LKPD DI PEMERINTAH KABUPATEN-KOTA DI PROVINSI PAPUA
}

\author{
Sria Kogoya ${ }^{1}$ \\ chialany@gmail.com \\ Dr. Agustinus Salle, SE., M.Ec ${ }^{2}$ \\ Anthonius H. Citra Wijaya, SE., M.Sc., Ak., $\mathrm{CA}^{3}$ \\ Jurusan Akuntansi, Fakultas Ekonomi dan Bisnis Universitas Cenderawasih
}

\begin{abstract}
The population in this study is regencies / cities in the Papua Province during the last three years, namely the 2015-2017 budget year, the data obtained is the LHP data that has been audited by the $B P K$. the sample used in all of these studies as many as 87 samples of local government financial reports are all existing populations in the sample. The data analysis method used in this study uses multiple linear regression analysis with the SPSS 16 program. This data is processed from June to the beginning of the 2019 julli in Jayapura City, Papua Province. The results in this study indicate that the age of the Regional Government has a positive effect on the level of disclosure of regional financial statements (LKPD). and on the Local Government Size, the Number of OPD, and also the Dependency Rate have a positive and insignificant effect on the level of disclosure while the audit findings themselves influence the level of disclosure of the LKPD.
\end{abstract}

Keywords : Local Government Size, Age of Local Government, Audit Findings, Number of Dpos, and the level of Fiscal Dependence

\section{PENDAHULUAN}

Dalam undang-undang telah diamanatkan oleh negara kepada pemerintah daerah sebagai daerah otonomi, berdiri sendiri (mandiri) dimaksudkan dalam hal pengelolaan keuangan daerah juga mempertanggung jawabkan laporan tersebut kepada pemerintah pusat, DPRD ataupun masyarakat. Sebagai upaya dari pemerintah agar dapat melaksanakan undang-undang tersebut untuk mewujudkan sebuah tata kelola pemerintah yang baik menggunakan cara menjalankan pemerintahan dengan efektif, efisien, dan juga transparan yang terpenting dalam pengelolaan dan pertanggungjawaban keuangan, pemerintah seta dewan perwakilan rakyat juga sudah mengesahkan undang-undang Nomor17 Tahun 2003 mengenai keuangan negara dan undang-undang nomor 15 Tahun 2004 tentang pemeriksaan keuangan dan tanggung jawab keuangan negara.

Keuangan Daerah menurut PP No.58 Tahun 2005 yaitu tentang semua hak juga kewajiban suatu daerah dalam rangka penyelenggaraan pemerintah daerah yang dapat Pelaksanaan Anggaran memandatkan bahwa anggaran yang disetujui oleh DPRD pada tingkat kegiatan dan "wajib menyajikan rincian fungsi, urusan pemerintahan, organisasi, program, kegiatan, jenis, obyek dan rincian obyek belanja" (pasal 23 (2). Salah satu konsekuensi mewajibkan rincian pada tingkat kegiatan (satu tingkat di bawah program) adalah DPRD harus menyetujui anggaran di tingkat pengguna anggaran (SKPD) bukan ditingkat yang lebih tinggi yaitu tingkat dinas. Persetujuan pada tingkat yang terinci itu membuat anggaran menjadi tidak fleksibel dalam pelaksanaannya dan secara signifikan

\footnotetext{
${ }^{1}$ Alumni Jurusan Akuntansi FEB Uncen

${ }^{2}$ Dosen Jurusan Akuntansi FEB Uncen

3 Dosen Jurusan Akuntansi FEB Uncen
} 
menyebarkan tanggungjawab pelaksanaan anggaran.

Untuk menjalankan undang-undang tersebut maka kementerian dalam negeri mengeluarkan Peraturan Menteri Dalam Negeri Nomor 64 Tahun 2013 tentang pemaparan standar akuntansi pemerintah pemerintahan berbasis akrual terhadap pemerintah daerah(Berita Negara Republik Indonesia Tahun 2013 Nomor 1425).

Peraturan Menteri Dalam Negeri Nomor 64 Tahun 2003 Pasal 1 Point 15 mengatakan bahwa pengungkapan yaitu laporan keuangan yang disajikan secara lengkap semua informasi yang dibutuhkan buat setiap pengguna.dan berikutnya untuk poin yang ke 16 sampai 22 menyatakan komponen dalam laporan keuangan pemerintah baik pusat maupun daerah diantaranya Laporan Realisasi Anggaran (LRA), Laporan Perubahan Saldo Anggaran Lebih (LPSAL), Neraca, Laporan Operasional (LO), Laporan Arus Kas (LAK), Laporan Perubahan Ekuitas (LPE), dan Catatan Atas Laporan Keuangan (CALK).

Pedoman Standar Akuntansi Pemerintah (PSAP) Nomor 1 Paragraf 24 menyatakan bahwa entitas pelaporan mengungkapkan informasi tentang ketaatan pada anggaran. Dan seterusnya pun sama menjelaskan pentingnya pengungkapan seluruh informasi keuangan yang diperlukan pengguna karena hal ini untuk menghindari adanya kekeliruan juga kesalahpahaman saat membaca laporan. Pemenuhan saat adanya pengungkapan akan memudahkan pengguna laporan keuangan saat memahami isi dari laporan keuangan tersebut, pengungkapan laporan keuangan ini juga bersifat wajib persis seperti PSAP yang pasti dijadikan dasar didalam penelitian ini.

Pedoman standar akuntansi pemerintah PSAP sangat dibutuhkan bagi setiap pemerintahan untuk menjadi pedoman dalam membuat laporan keuangan yang baik dan juga mempunyai daya banding sehingga dapat memberikan informasi yang sangat berharga bagi para pihak yang berkepentingan. Standar akuntansi sendiri merupakan suatu landasan dan petunjuk bagi pemerintah agar membuat praktek ataupun kegiatan dalam bidang akuntansi pemerintahan hingga dapat menghasilkan laporan akuntabel sama seperti amanah undang-undang.

Adapun beberapa faktor yangdapat membuat hasil penelitian menjadi berbeda yaitu ukuran pemerintah daerah, umur pemerintah daerah, temuan audit, tingkat ketergantungan, diferensiasi fungsional (SKPD/OPD) .

Ukuran Organisasi memperlihatkan seberapa besar sebuah organisasi tersebut. Organisasi yang besar semangat cenderung mempunyai banyak sekali aturan dan juga ketentuan dari pada organisasi yang kecil (Syafitri dan Setyaningrum ,2012). Setiap pemerintah daerah yang mempunyai transparansi pada pengelolaan keuangannya sebagai bukti dari akuntabilitas publik lewat pengungkapan informasi yang sangat banyak didalam laporan keuangan.

Umur Pemerintah Daerah bisa diartikan dengan seberapa lama suatu organisasi tersebut ada didasarkan pada undang-undang yang menjelaskan tentang pembentukan pemerintah daerah. Pemerintah daerah yang mempunyai usia administratif lebih lama maka akan semakin berpengalaman dan juga pasti memiliki kemampuan yang sangat baik dalam menyiapkan laporan keuangan secara wajar sesuai juga dengan SAP (Walliyani dan Mahmud, 2015).

Temuan-temuan audit BPK merupakan setiap kasus-kasus yang sudah didapatkan oleh BPK terhadap semua laporan keuangan pemerintah daerah pada setiap pelanggaran yang sudah dilakukan suatu daerah terhadap ketentuan pengendalian intern ataupun terhadap ketentuan perundang-undangan yang berlaku. Dan jika semakin besar yang ditemukan maka akan semakin besar jumlah tambahan pengungkapan yang bisa diminta oleh BPK didalam laporan keuangannya.

Diferensiasi fungsional pada pemerintah daerah kabupaten juga kota sangat dikenal dengan nama satuan kerja perangkat daerah (SKPD) dan untuk tahun 2017 diubah nama menjadi organisasi perangkat daerah (OPD). Jumlah SKPD di masing-masing pemerintah daerah menggambarkan jumlah keperluan yang diutamakan pemerintah daerah untuk membangun daerah tersebut. Didalam setiap hal 
tentang laporan pertanggungjawaban merupakan kumpulan laporan dalam masing- masing SKPD hingga semakin banyak SKPD maka semakin kompleks pula laporan keuangan yang dibuat.

Sehingga tujuan penelitian ini adalah untuk menguji dan mengetahui pengaruh ukuran pemerintah daerah, umur pemerintah daerah, temuan audit, jumlah SKPD/OPD dan hasil ketergantungan fiskal terhadap tingkat pengungkapan Laporan Keuangan Pemeringah Daerah (LKPD).

\section{LANDASAN TEORI}

\subsection{Teori Stewarship}

Secara umum tujuan dari laporan keuangan yaitu memberikan setiap informasi mengenai posisi keuangan, kinerja maupun arus kas yang berguna bagi setiap keputusan ekonomi serta dapat menunjukkan pertanggungjawaban (stewardship) manajemen dalam penggunaan sumber-sumber daya yang telah dipercayakan kepadanya. Ada pula yang dimaksud sebagai wujud pelaksanaan Good Gavernance yang sangat baik seperti upaya dalam pertanggungjawaban lewat pembuatan laporan keuangan. Agar tercapai hal tersebut maka sebuah pengungkapan yang jelas dan dapat dipahami sangat diperlukan mengenai setiap data akuntansi maupun informasi lainnya yang pasti haruslah relevan.

Teori stewardship yaitu teori yang menggambarkan sebuah situasi dimana setiap manajer tidak dapat termotivasi atau terdorong dengan tujuan individu seperti halnya uang dan materi, tetapi teori ini sangat dibutuhkan pada setiap sasaran dan target dalam hasil utamanya untuk kepentingan organisasi (Rahahrjo ,2007). Teori ini memiliki dasar psikologis dan sosiologi yang sudah dirancangkan untuk setiap eksekutif yang termotivasi sebagai pihak penerima amanah (steward) akan bertindak sesuai dengan keinginan pihak pemberi amanah (principal).

Didalam pemerintahan harus memiliki banyak informasi dan juga bertanggungjawab pada kepercayaan yang sudah diberikan oleh rakyat (pada saat pemilihan umum) dan juga harus memiliki kesadaran untuk mewujudkan transparansi dan akuntabilitas. Dengan adanya kesadaran ini suatu upaya untuk mengaktualisasi diri sebagai pegawai pemerintah yang patuh maupun sebagai tujuan dalam politik seperti mencari simpati supaya terpilih dalam pemilu yang mendatang, dan juga upaya dalam memperoleh kepercayaan dari masyarakat.

\subsection{Tingkat Pengungkapan Laporan Keuangan Pemerintah Daerah}

Dalam PSAP Nomor 01 paragraf 13 disebutkan tanggung jawab penyusunan dan penyajian laporan keuangan berada pada pimpinan entitas, sedangkan komponen-komponen yang terdapat dalam suatu set laporan keuangan pokok adalah Laporan Realisasi Anggaran, Neraca, Laporan Arus Kas, dan Catatan Atas Laporan Keuangan (PSAP Nomor 01 paragraf 14). StandarAkuntansi Pemerintah (SAP) yang diatur oleh Peraturan Pemerintah Nomor 71 Tahun 2010 menjelaskan bahwa laporan keuangan merupakan laporan yang telah terstruktur mengenai sikap posisi keuangan, maupun transaksi-transaksi yang telah dibuat oleh suatu pelaporan.

Laporan keuangan pada dasarnya adalah hasil dari posisi akuntansi yang dapat digunakan sebagai alat untuk berkomunikasi dengan data keuangan atau aktivitas suatu perusahaan atau pemerintahan dengan pihak-pihak yang berkepentingan dengan data atau aktivitas suatu pemerintahantersebut. Laporan keuangan juga menyajikan informasi keuangan suatu entitas selama periode tertentu yang dapat menggambarkan suatu kinerja entitas tersebut. Laporan keuangan sebagai sarana informasi yang secara formal memang harus dipublikasikan sebagai bukti pertanggungjawaban pihak manajemen kepada pengelola sumber daya pemilik, serta jendela informasi juga mungkinkan bagi setiap bagi setiap pihak-pihak yang berada diluar manajemen mengetahui kondisi entitas tersebut Susanti, (2010) dalam Handayani dan Kusuma (2017).

Laporan keuangan pemerintah daerah (LKPD) salah satu bentuk pertanggungjawaban pemerintah daerah terhadap masyarakat tentang sumber daya ekonomi (aktiva) dan kewajiban dalam 
suatu entitas pemerintah pada periode yang ditentukan disusun sesuai dengan Standar Akuntansi Pemerintah (SAP). Laporan keuangan pemerintah daerah (LKPD)yang komprehensif yaitu suatu alat yang dapat mendukung terciptanya sebuah transparansi dalam akuntabilitas publik.

Sebuah alat yang dapat mendukung terciptanya sebuah transparansi akuntabilitas publik yaitu, melalui penyajian laporan keuangan pemerintah daerah. Tujuan dari pelaporan keuangan untuk kepentingan:

a.) Akuntabilitas, yang diartikan sebagai pertanggungjawaban pengelolaan sumber daya dan pelaksanaan kebijakan yang sudah dipercayakan kepada setiap entitas pelaporan untuk mencapai tujuan yang sudah ditetapkan.

b.) Manajemen, yang dimaksud yaitu membantu setiap pengguna untuk mengevaluasi pelaksanaan kegiatan sebuah entitas pelaporan dalam periode pelaporan agar dapat mempermudah fungsi perencanaan, pengelolaan, dan juga pengendalian pada setiap aset, kewajiban, dan ekuitas dana pemerintah dalam kepentingan pemerintah

c.) Transparansi, adalah untuk memberikan setiap informasi keuangan yang terbuka dan juga jujur kepada setiap masyarakat dengan pertimbangan bahwa masyarakat juga mempunyai hak untuk mengetahui semua informasi secara wajar, terbuka, juga transparan dan menyeluruh atas akuntabilitas pemerintah pada pengelolaan sumber daya yang telah dipercayakan kepada mereka dan juga ketaatan terhadap peraturan perundang-undang.

d.) Keseimbangan antar generasi, yaitu menolong setiap pengguna dalam mengetahui kecukupan pada penerimaan pemerintah di periode pelaporan waktu membiayai semua pengeluaran yang telah di alokasikan dan juga apakah generasi selanjutnya diasumsikan akan menanggung setiap beban pengeluaran tersebut.

\subsection{Penelitian Terdahulu}

Dalam hal ini adapun peneliti-peneliti terdahulu yang sudah lebih dulu melakukan penelitian mereka dengan berbagai macam judul yang hampir sama dengan judul yang dibuat oleh penulis seperti dibawah ini

Penelitian yang dibuat oleh Hendriyani dan Tahar,(2015) yang melakukan penelitian menggunakan variable independen berdasarkan karakteristik pemerintah yaitu tingkat ketergantungan berdasarkan kompleksitas pemerintah yaitu jumlah penduduk dan berdasarkan hasil temuan audit yang ditemui audit.dan peneliti menambah dua variabel yaitu PAD dan belanja modal penelitian ini dilakukan di pemerintah provinsi Indonesia.

Penelitian yang dibuat oleh Mahmud dan Willyyani(2015) menunjukkan pengaruh karakteristik pemerintah terhadap tingkat pengungkapan laporan keuangan pemerintah daerah yang ada di Indonesia, yang meneliti pengaruh ukuran( size), umur pemerintah daerah, temuan audit, jumlah OPD, dan juga tingkat ketergantungan terhadap tingkat pengungkapan LKPD. Dan hasil penelitian ini memperlihatkan bahwa size juga temuan pada audit berpengaruh positif tidak signifikan terhadap tingkat pengungkapan laporan keuangan pemerintah daerah. Sedangkan variabel dalam umur pemerintah daerah sendiri berpengaruh positif signifikan terhadap tingkat pengungkapan laporan keuangan pemerintah daerah, dan juga variabel tingkat ketergantungan menunjukkan hasil yang negatif dan tidak signifikan terhadap tingkat pengungkapan laporan keuangan. 


\subsection{Pengembangan Hipotesis}

\subsubsection{Ukuran Pemerintah Daerah Terhadap Tingkat Pengungkapan LKPD}

Suatu daerah yang mempunyai ukuran total aset lebih besar maka akan memiliki tuntutan yang lebih besar pula agar dapat mengungkapkan lebih banyak lagi LKPD. Total aset yang lebih besar juga kompleks memerlukan pengelolaan aset yang sangat baik sehingga pengungkapan bisa lebih besar terkait pemeliharaan juga penatausahaan aset (Hasnah, 2014). Selain dari itu, adapun total aset yang besar dan kompleks memerlukan pengungkapan yang sangat banyak agar terkait rincian masingmasing aset, kebijakan akuntansi yang juga digunakan, metode penyusutan, dan juga kondisi dan kepemilikan aset. Maka berdasarkan hasil penelitian yang penulis lakukan yaitu.

H1 : ukuran pemerintah daerah berpengaruh positif tidak signifikan terhadap tingkat pengungkapan laporan keuangan pemerintah daerah LKPD.

\subsubsection{Umur Pemeritah Daerah Terhadap Tingkat Pengungkapan LKPD}

Dalam suatu pemerintahan dapat dilihat dari sebuah umur, yang dimaksud dengan umur disini adalah terbentuknya sebuah daerah yang telah berdiri dengan pemerintahan sendiri. Jadi sebuah hubungan positif signifikan dapat terjadi karena umur dari pemerintah daerah dan juga umur administratif yang semakin tua maka akan semakin banyak pula informasi yang dihasilkan untuk dapat diungkapkan daripada suatu pemerintah daerah yang masih muda umur administratif atau baru berdiri.maka dari itu hasil yang ditemukan oleh penulis dalam penelitian ini adalah:

H2 : Umur Pemerintah Daerah berpengaruh positif signifikan terhadap setiap laporan keuangan pemerintah daerah LKPD.

\subsubsection{Hasil Temuan Audit Terhadap Tingkat Pengungkapan LKPD}

Temuan-temuan audit BPK merupakan setiap kasus-kasus yang sudah didapatkan oleh BPK terhadap semua laporan keuangan pemerintah daerah pada setiap pelanggaran yang sudah dilakukan suatu daerah terhadap ketentuan pengendalian intern ataupun terhadap ketentuan perundang-undangan yang berlaku.

Dalam hasil penelitian Hilmi 2012 dan Ernawati 2016 memperlihatkan suatu ukuran pemerintah daerah yang berpengaruh positif terhadap setiap tingkat pengungkapan LKPD.Maka berdasarkan hasil penjelasan tersebut, peneliti dapat menentukan terbentuk suatu hipotesis berikut

H3 : Dalam Temuan Audit berpengaruh negatif tidak signifikan terhadap tingkat pengungkapan LKPD.

\subsubsection{Jumlah SKPD/OPD Terhadap Tingkat Pengungkapan LKPD}

Semakin kompleks suatu pemerintahan yang didalamnya menjalankan kegiatan yang akan menyebabkan semakin besar sebuah tingkat pengungkapan yang dilakukan.semakin kompleks pemerintahan sangat diutuhkan pengungkapan yang pasti lebih besar agar dapat membantu setiap pembaca laporan keuangan untuk memahami semua kompleksitas kegiatan yang dilaksanakan oleh suatu pemerintah. maka peneliti mencoba menggunakan jumlah SKPD/OPD sebagai salah satu proksi agar dapat menjelaskan kompleksitas. Dengan begitu berdasarkan dari hasil penelitian tersebut maka dibentuk sebuah hipotesis sebagai berikut.

H4 : SKPD/OPD berpengaruh positif tidak signifikan terhadap tingkat pengungkapan LKPD.

\subsubsection{Tingkat Ketergantungan Fiskal Terhadap Tingkat Pengungkapan LKPD}

Yang dimaksud dengan dana transfer yaitu sebuah jenis pendanaan daerah yang diterima dari pemerintah pusat ataupun provinsi. Suatu tingkat ketergantungan suatu daerah dijadikan sebagai pendapatan dalam pemerintah daerah tersebut untuk dapat membiayai operasi pemerintah daerah. Dan sebagai timbal baliknya pemerintah daerah tersebut membelanjakan pendapatan transfer antar 
pemerintah sesuai pada setiap alokasi dan juga petunjuk dalam anggaran menurut undang-undang.

Maka dari itu berarti semakin besar tingkat ketergantungan maka akan semakin besar juga suatu tingkat pengungkapan yang dibuat oleh pemerintah daerah.

H5 : Tingkat Ketergantungan berpengaruh positif tidak signifikan terhadap tingkat pengungkapan LKPD.

\section{METODE PENELITIAN}

Sampel yang digunakan penulis dalam penelitian yang dilakukan ini adalah LKPD kabupaten dan kota yang ada di provinsi papuapada tahun 2015-2017.di Indonesia saat ini memiliki 33 provinsi .sampel yang dipilih berdasarkan ketersediaan data LKPD dan hanya diambil di provinsi papua dengan 28 kabupaten dan 1 kota selama tiga tahun terakhi. Data yang digunakan ini dimiliki dari berbagai sumber. Data yang dipakai untuk LKPD ini sendiri diperoleh dari BPK dan untuk mengukur dan melihat temuan audit juga tingkat pengungkapan LKPD dan tingkat ketergantungan itu sendiri dan untuk umur pemda, jumlah SKPD dapat dilihat dari websait pemerintah.

Penelitian ini penulis menggunakan uji analisis regresi berganda dengan memakai analisis data panel. Dengan system perumusan dan diefini sebagai berikut

\section{Pengukuran variabel}

\begin{tabular}{|c|c|c|c|}
\hline abel & hisis & ukuran & rensi \\
\hline $\begin{array}{l}\text { kat } \\
\text { pengungkapan } \\
\text { LKPD }(Y)\end{array}$ & $\begin{array}{l}\text { kat pengungkapan LKPD ini } \\
\text { menggambarkan seberapa } \\
\text { besar pengungkapan yang } \\
\text { dilakukan oleh pemerintah } \\
\text { daerah dibandingkan dengan } \\
\text { pengungkapan rang } \\
\text { seharusnya disajikan }\end{array}$ & $\begin{array}{l}\text { CLOSURE }= \\
\text { ungkapan } \\
\text { LKPD } \\
\text { ungkapan } \\
\text { PSAP }\end{array}$ & $\begin{array}{l}\text { udin Zul } \\
\text { i dan } \\
\text { Martani } \\
2\end{array}$ \\
\hline $\begin{array}{l}\text { an pemerintah } \\
\text { daerah }\end{array}$ & $\begin{array}{l}\text { an pemerintah daerah adalah } \\
\text { besarnya kekayaan atau } \\
\text { dihitung dengan total aset } \\
\text { yang dimiliki oleh daerah } \\
\text { dalam setahun }\end{array}$ & $i=$ Ln Total Aset & arjo (2010) \\
\hline $\begin{array}{l}\mathrm{r} \quad \text { Pemerintah } \\
\text { Daerah }\end{array}$ & $\begin{array}{lll}\text { r pemerintah daerah } & \text { dapat } \\
\text { diartikan seberapa } & \text { lama } \\
\text { pemerintah daerah ada. } & \end{array}$ & $\begin{array}{l}=\text { Umur } \quad \text { Pemda } \\
\text { berdasarkan hari jadi } \\
\text { terkait }\end{array}$ & anah (2014) \\
\hline ah Temuan Audit & $\begin{array}{l}\text { uan audit adalah kasus-kasus } \\
\text { yang di temukan dalam } \\
\text { laporan keuangan pemerintah } \\
\text { daerah. }\end{array}$ & $\begin{array}{l}\text { uan Audit = } \\
\text { ah Temuan }\end{array}$ & r (2015) \\
\hline ah SKPD & $\begin{array}{lr}\text { D adalah pelaksana fungsi } \\
\text { eksekutif yang } & \text { harus } \\
\text { berkoordinasi } & \text { agar } \\
\text { penyelenggaraan pemerintaha } \\
\text { berjalan baik. }\end{array}$ & $\mathrm{D}=$ Jumlah SKPD & 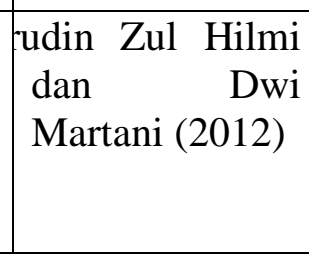 \\
\hline $\begin{array}{l}\text { kat } \\
\text { Ketergantungan }\end{array}$ & $\begin{array}{l}\text { govermental revenue adalah } \\
\text { jenis pendapatan pemeintah } \\
\text { daerah yang berasal dari } \\
\text { transer pemerintah pusat } \\
\text { kepada pemerintah daerah } \\
\text { untuk membiayai operasi } \\
\text { pemerintah daerah }\end{array}$ & $\begin{array}{l}\text { PV = Total Dana } \\
\text { Perimbangan } \\
\text { Pendapatan }\end{array}$ & anah (2014) \\
\hline
\end{tabular}




\section{HASIL PENELITIAN DAN PEMBAHASAN}

\subsection{Gambaran Umum Objek Penelitian}

Populasi yaitu keseluruhan jumlah yang terdiri dari obyek atau subyek yang mempunyai katakteristik dan kualitas tertentu yang diterapkan oleh peneliti untuk diteliti dan kemudian ditarik kesimpulannya. Sedangkan sampel adalah bagian dari sejumlah karakteristik yang dimiliki oleh populasi yang digunakan untuk penelitian. Bila populasi besar peneliti tidak mungkin mengambil semua untuk menelitikarena terbatasnya dana, tenaga, dan waktu, maka peneliti dapat menggunakan sampel yang diambil saja.

Populasi dalam penelitian yang disunakan ini adalah Pemerintah Daerah Kabupaten dan Kota di Provinsi Papua, jumlah pemerintah daerah kabupaten/kota yang ada di Provinsi Papua adalah sebanyak 29 pemerintah daerah, yang terdiri dari 1 (satu) pemerintah kota dan 28 pemerintah kabupaten. Sedangkan sampel yang digunakan adalah Laporan Keuangan Pemerintah Daerah pada Pemerintah Daerah Kabupaten/Kota di Provinsi Papua periode tahun 2015-2017. Penelitian dilakukan pada sampel selama tahun 2015 sampai dengan tahun 2017 sehingga penelitian ini menggunakan seluruhnya 87 unit analisis. Data ini diajukan utuk diolah pada tanggal 28 mei 2019 namun terjawab bulan juni 2019 maka data ini diolah pada bulan juni 2019 sampai awal juli 2019, untuk dapat melihat nila yang signifikan juga baik terhadap “Analisis Faktor-Faktor Yang Mempengaruhi Tinggkat Penggungkapan LKPD”

\subsection{Statistik Deskriptif}

Berdasarkan tabel 1 menunjukaan setiap hasil deskripti dari 87 LKPD yang ada pada kabupaten/kota di provinsi papua dalam tahun anggaran 2015-2017.

a) Berdasarkan dari hasil perhitungan nilai rata-rata pada ukuran pemerintah yang telah diukur dengan total asset sebesar 14.8160. nilai untuk ukuran pemerintah daerah yang terendah (minimum) sebesar 12,02 terdapat di Kabupaten Deiyai pada tahun 2015 Dan nilai tertinggi pada pemerintah daerah (maksimum) sebesar 16.61 terdapat di Kabupaten Merauke pada tahun 2015. Nilai pada standar deviasi sebesar 1.17540.

b) Berdasarkan pada setiap hasil perhitungan selama tiga periode dalam pengamatan nilai rata-rata pada setiap umur peerintah daerah yang sudah diukur berdasarkan hari jadi daerah tersebut yaitu sebesar 22,86. Nilai termudah pada pemerintah daerah (minimum) adalah 7 tahun terdapat pada beberapa kabupaten yang baru di mekarkan. Dan milai pada pemerintah daerah yang paling lama atau tertua (maksimum) adalah 115 tahun yang terdapat di Kabupaten Merauke. Terdapat juga nilai standar deviasi yaitu sebesar 28.307.

c) Pada hasil perhitungan dalam periode pengamatan berdasarkan nilai rata-rata untuk setiap temuan audit yang telah diukur dengan jumlah temuan tersebut yaitu sebesar 17.06. adapun niali terendah dari temuan audit ini (minimal) yaitu sebanyak 6 temuan di Kabupaten Asmat pada tahun 2015. Adapun nilai tertinggi pada hasil penelitian ini (maksimum) yaitu 35 temuan terdapat di Kabupaten Tolikara periode 2015 . Dalam nilai standar deviasi juga mendapatkan hasil sebesar 4.113.

d) Berdasarkan hasil perhitungan selama periode pengamatan nilai rata-rata dalam organisasi perangkat daerah OPD yang diukur dengan jumlah OPD adalah sebesar 22,66. Adapun nilai OPD terendah (minimum) yaitu sebesar 10 OPD yang terdapat pada Kabupaten Ndugah. Dan nilai tertinggi (maksimum) sebesar 53 OPD yang terdapat di pemerintah Kabupaten Jayapura. Nilai standar deviasi yaitu sebesar 8,801 .

e) Berdasarkan hasil perhitungan pada periode pengamatan nilai rata-rata dalam tingkat ketergantungan yang dihitung dengan perbandingan total dana perimbangan dan total pendapatan adalah sebesar 16,3632. Dan nilai terendah tingkat ketergantungan (minimum) yaitu 00 terdapat di beberapa kabupaten. Adapun nilai tertinggi pada tingkat ketergantunga 
(maksimum) yaitu sebesar 13,7538 terdapat di pemerintah Kabupaten Puncak Jaya. Nilai standar deviasi sebesar 147,39851.

\subsection{Uji Asumsi Klasik}

\section{a. Uji Normalitas}

Uji Normalitas data merupakan sebuah syarat yang mutlak sebuah data dapat dinalisis dan digunakan untuk mengetahui apakah residual dari suatu model regresi terdistribusi normal atau tidak.persyaratan dari uji normalitas residual adalah jika nilai dari skweness dan kurtosis sebesar \pm 1.96 (dengan taraf signifikan atau alpha 0,05). Maka hasil regresi akan memenuhi asumsi normalitas. Hasil uji normalitas dapat dilihat pada tabel 2 berikut ini. Berdasarkan tabel 2 nilai skweness dan kurtosis dapat dihitung dengan rumus sebagai berikut :

Rumus rasio skewness $=$ statistic skewness $/$ std.error skewness

Skewness $=0.365 / 0,258$

$$
=1,414729
$$

Rumus rasio kurtosis = statistic kurtosis / std.error kurtosis

$$
\begin{aligned}
\text { Kurtosis } & =0.186 / 0,511 \\
& =0.363992
\end{aligned}
$$

Berdasarkan hasil output uji Normalitas diatas, diperoleh nilai skewness sebesar 1,414729 $< \pm 1$,96 dam kurtosis sebesar 0,363992 < $\pm 1,96$ (dengan tingkat signifikan 0,05). Hasil uji tersebut memenuhi syarat, sehingga model regresi dalam penelitian ini memiliki data yang terdistribusi normal.

\section{b. Uji Multikolinearitas}

Berdasarkan tabel 3 hasil perhitungan nilai tolerance menunjukan tidak ada variabel independen yang memiliki nilai tolerance kurang dari 0,10 yang berarti tidak terjadi korelasi antar variabel independen sehingga dapat disimpulkan bahwa tidak terjadi multikolinearitas antar variabel independen dalam uji regresi ini. Dari hasil perhitungan yang ada pada tabel hasil uji multikolinearitas variable bebas menunjukan bahwa nilai VIF $=1$ dimana nilai tersebut lebih kecil dari 10 sehingga dapat disimpulkan Bebas dari multikolinearitas.

\section{c. Uji Autokorelasi}

Berdasarkan nilai tabel uji autokorelasi diketahui untuk nilai $\mathrm{DW}=1.718$ dibandingkan denganilai tabel signifikansi 5\% (0,05) dengan jumalh sampel 87 dan jumlah varian variabel independen $5(\mathrm{k}=5)$ $=5,87$ sehingga didapatkan hasil dU dari tabel $\mathrm{r}=1,477$ maka nilai DW lebih besar dari batas dU dan kurang dari $(4-\mathrm{dU})=4-1,477=2,523(\mathrm{du}<\mathrm{dw}<4-\mathrm{du})$.maka dapat disimpulkan bahwa model terbebas dari autokorelasi positif maupun negatif.

\begin{tabular}{|l|l|l|l|l|}
\hline $\begin{array}{l}\text { Autokorelasi } \\
\text { negative }\end{array}$ & $\begin{array}{l}\text { Tidak ada } \\
\text { kesimpulan }\end{array}$ & $\begin{array}{l}\text { Tidak ada } \\
\text { autokorelasi }\end{array}$ & $\begin{array}{l}\text { Tidak ada } \\
\text { kesimpulan }\end{array}$ & $\begin{array}{l}\text { Autokorelasi } \\
\text { positif }\end{array}$ \\
\hline \\
dl.1.5634 du. $1.477\lfloor$ 4-du.2.532 4-dl.2.4366 \\
\hline
\end{tabular}

$\mathrm{DW}=1.718$

Nilai DW sebesar 1.718 berada diantara du 1,477dan 4-1,477 sehingga tidak terjadi autokorelasi. 


\section{d. Uji Heterokedastisitas}

Pada tabel 5 setelah dilakukan uji park menunjukan bahwa semua variabel independen dalam model ini tidak signifikan, yang artinya adalah secara statistik tidak mempengaruhi veriabel dependen karena nilai ppropabilitas signifikannya diatas tidak kepercayaan 0,05.sehingga disimpulkan bahwa dalam model regresi tidak terjadi heteroskedasitas.

\subsection{Uji Regresi Berganda}

Berdasarkan pada tabel 6 diatas dapat diketahui bahwa entimasi model regresi adalah sebagai berikut : DISCLOSURE =0,478 + 0,002x1 + 0,002 $22-0,002 \times 3+0,001 \times 4+5,010 E-5 \times 4+e$

Keterangan:
a. Disclosure :Tingkat Pengungkapan LKPD
b. X1
:Ukuran Pemerintah Daerah
c. $\mathrm{X} 2$
:Umur Pemerintah Daerah
d. $X 3$
:Temuan Audit
e. $\mathrm{X} 4$
:OPD
f. X5
:Tingkat Ketergantungan
g. $e$
:Error

Berdasarkan hasil dari tabel 6 maka Disclosure untuk mengukur kekuatan bagi hubungan antara tingkat pengungkapan dapat diukur tidak memiliki kekuuatan pada Temuan audit karena memiliki nilai $-0,002$ mines.

\subsection{Hasil Pengujian Hipotesis}

\section{a. Uji Koefisien Determinasi}

Berdasarkan tabel 7 nilai koefisien determinasi ditunjukan dengan nilai adjusted $\mathrm{R}^{2}$ sebesar 0,332. Hal ini menunjukan bahwa variabilitas variabel dependen yang dapat dijelaskan oleh variabilitas variabel independen sebesar 33,2\% variasi pada tingkat pengungkapan LKPD dapat dijelaskan oleh variabel independen yaitu pada ukuran pemerintah daerah, umur pemerintah daerah, temuan audit, jumlah OPD, tingkat ketergantungan. Sedangkan sisanya $(100 \%-33,2 \%=66,8 \%)$ dijelaskan oleh variabel lain diluar dari model penelitian. Standar Error of estimate (SEE) sebesar 0,09720 ribu. Makin kecil nilai SEE akan membuat model regresi semakin tepatdalam memprediksi variabel dependen.

\section{b. Uji F}

Dari uji anova atau $\mathrm{f}$ test didapat nilai $\mathrm{F}$ dihitung sebesar 9,544 dengan signifikan sebesar $0,000^{\mathrm{a}}$. Dibawah batas nilai kritis sebesar 5\% (0,05). Jadi dapat disimpulkan bahwa setiap data model penelitian : Tingkat Ketergantungan, Ukuran Pemerintah Daerah, Jumlah OPD, Umur Pemerintah Daerah dan Temuan Audit, terhadap Tingkat Pengungkapan LKPD adalah model yang layak (fit).

\section{c. Uji t}

Berdasarkan hasil pengujian yang dilakukan bulan juni 2019 sampai awal juli 2019 terdapat dalam tabel 9 memperlihatkan bahwa nilai t sebesar 0,235 sedangkan nilai sig sebesar $-0,815$ yang artinya lebih besar dari tingkat signifikansi 0,05, sehingga $\mathbf{H 1}$ ditolak dan dapat disimpulkan bahwa ukuran pemerintah daerah berpengaruh positif tidak signifikansi (tidak berpengaruh) terhadap tingkat pengungkapan LKPD.

Berdasarkan hasil pengujian yang dilakukan bulan juni 2019 sampai awal juli 2019 pada tabel 9 memperlihatkan nilai t sebesar 5,419 sedang nilai sig sebesar 0,000 yang artinya lebih kecil dari nilai signifikansi 0,05 sehingga $\mathbf{H 2}$ diterima dan dapat disimpulkan bahwa umur pada pemerintah daerah berpengaruh positif signifikansi terhadap tingkat pengungkapan LKPD. 
Berdasarkan pada hasil pengujian yang dilakukan bulan juni 2019 sampai awal juli 2019 tabel 9 diatas menunjukan nilai $\mathrm{t}$ sebesar - 0,850 sedangkan pada nilai sig sebesar 0,398 yang artinya lebih besar dari nilai signifikansi 0,05, sehingga H3 ditolak dan dapat disimpulkan bahwa ukuran pemerintah daerah berpengaruh negatif tidak signifikansi terhadap tingkat pengungkapan LKPD. Karena nilai hipotesis $t$ besar namun ada minesnya dan nilai sig juga besar dibandingkan dengan nilai signifikansi yang sudah ditetapkan maka disebut negative tidak signifikan ..Dari hasil ini jumlah temuann audit BPK tidak mendorong pemerintah untuk dapat melakukan pengungkapan yang lebih besar lag terhadapa LKPD.

Berdasarkan hasil pengujian yang dilakukan bulan juni 2019 sampai awal juli 2019 pada tabel 9 diatas memperlihatkan tentang nilai t sebesar 0,685 sedangkan pada nilai sig terd apat sebesar 0,495 yang artinya lebih besar dari nilai signifikansi 0,05 sehingga $\mathbf{H 4}$ ditolak dan dapat disimpulkan bahwa OPD berpengaruh positif tidak signifikansi (tidak berpengaruh) terhadap tingkat pengungkapan LKPD.

Berdasarkan hasil pengujian yang dilakukan bulan juni 2019 sampai awal juli 2019 pada tabel 4.9 diatas memperlihatkan tentang nilai t sebesar 0,703 sedangkan pada nilai sig terdapat sebesar 0,484 yang artinya lebih besar dari nilai signifikansi 0,05 sehingga $\mathbf{H 5}$ ditolak dan dapat disimpulkan bahwa tingkat ketergantungan berpengaruh positif tidak signifikansi (tidak berpengaruh) terhadap tingkat pengungkapan LKPD. Karena nilai uji hipotesis t lebih besar dan nilai sig juga besar dibandingkan dengan nilai signifikansi maka hipotsis ini disebut positif tidak signifikan.

\subsection{Pembahasan}

\subsubsection{Pengaruh Ukuran Pemerintah Daerah Terhadap Tingkat Pengungkapan LKPD}

Berdasarkan hasil pengujian yang dilakukan bulan juni 2019 sampai awal juli 2019 pada tabel uji t menunjukan bahwa ukuran pemerintah daerah berpengaruh positif tidak signifikan terhadap tingkat pengungkapan LKPD, yang berarti bahwa hipotesis satu (H1) ditolak. Maka dalam penelitian ini dijelaskan bahwa besaran kepemilikan asset oleh pemerintah tidak dapat mempengaruhi tingkat pengungkapan LKPD. Daerah dengan total asset yang besar cenderung memiliki sebuah kualiitas pengelolaan asset yang kurang baik dan juuga memperoleh catatan dari BPK. Namun setiap daerah yang ada seringkali tidak memiliki informasi yang cukup untuk terkait dengan permasalahan yang dihadapi (Walliyyani dan Mahmud 2015).

Hasil pada penelitian ini tidak dapat mendukung teori stewardship, yang menyatakan bahwa daerah dengan ukuran besar yang diproksikan dengan total asset memiliki kemungkinan yang lebih besar dalam upaya untuk dapat mewujudkan tanggungjawab steward melalui adanya suatu pengungkapan yang lebih besar pada ukuran daerah yang lebih besar. Besarnya suatu nilai asset itu tidak berpengaruh dalam memberikan tekanan kepada pemerintah agar lebih transparan atau terbuka dalam mengungkapkan asset sesuai SAP.

Hasil penelitian ini sama dengan penelitian yang telah dilakukan sebelumnya yaitu Hilmi (2012), Waliyyani dan Mahmud (2015), Girsang dan Yuyeta (2015), Hendriyani dan Tahar,(2015). Para peneliti ini mengemukakan bahwa ukuran pemerintah daerah berpengaru positif tidak signifikan terhadap tingkat pengungkapan LKPD.

\subsubsection{Pengaruh Umur Pemerintah Daerah Terhadap Tingkat Pengungkapan LKPD}

Berdasarkan pada hasil uji yang dilakukan bulan juni 2019 sampai awal juli 2019 menggunakan analisis uji t yang telah dilakukan pada tabel 9 maka hasil yang diperoleh adalah $\mathrm{H} 2$ atau umur pemerintah daerah berpengaruh positif signifikan terhadap tingkat pengungkapan laporan keuangan pemerintah daerah LKPD. Dalam penelitian ini sudah menjelaskan tingkat pengungkapan LKPD juga bergantung pada umur pemerintah karena adanya suatu sikap yang monoton dalam menyusun laporan keuangan. Selain itu lporan keuangan juga merupakan ilmu yang berkembang dinamis, sehinggah 
dapat menjamin bahwa suatu daerah yang sudah berdiri lama akan dapat menghasilkan laporan keuangan yang lebih baik, karena ditunjang oleh kemauan dan kemampuan pemerintah daerah dengan umur yang lebih tua dan pengalaman dalam menyusun laporan keuangan yang sudah semakin baik dan menjadi lebih baik.

Hasil ini mendukung teori stewardship yang menyatakan bahwa semakin tua umur suatu pemerintah daerah maka sudah bisa menunjukan tujuan dan kesadaran steward dengan lebih meyakinkan public bahwa daerah tersebut telah cukup mapan dan berpengalaman, sehingga masyarakat juaga akam merespon melalui harapan akan adanya pengungkapan yang lebih baik.

Hasil penelitian ini sangat menguatkan penelitian yang dilakukan Walliyani (2015) dan Setyaningrum(2012) yang menyatakan bahwa umur pemerintah berpengaruh positif signifikan terhadap tingkat pengungkapan LKPD, akan tetapi tidak mendukung penelitian sebelumnya yaitu Khasanah (2014) dan Suransi (2015) menunjukan umur pemerintah daerah berpengaruh negative tidak signifikan terhadap tingkat pengungkapan LKPD.

\subsubsection{Pengaruh Temuan Audit Terhadap Tingkat Pengungkapan LKPD}

Berdasarkanpengujian yang dilakukan bulan juni 2019 sampai awal juli 2019 menggunakan uji tes yang pada tabel 9 diatas, maka temuan audit dalam H3 tersebut ditolak karena berpengaruh negatif tidak signifikan terhadap tingkat pengungkapan LKPD.semakin sedikit temuan audit saat mengaudit laporan keuangan daerah maka akan semakin rendah pula tingkat pengungkapan LKPDnya, sehingga cenderung memiliki tingkat pengungkapan yang lebih rendah. Berdasarkan data yang digunakan sebagai sampel penelitian, sebagian besar hasil temuan audit yang ditemukan BPK yaitu temuan ketidakpatuhan atas semua peraturan perundang-undangan dan temuan pengendalian intern yang tidak terkait langsung dengan pelaporan keuangan daerah.

Dengan adanya temuan ini maka BPK akan meminta melakukan koreksi dan meningkatkan pengungkapannya. Sehingga semakin besar jumlah tamuan maka semakin besar tambahan pada tingkat pengungkapan yang akan diminta oleh BPK dalam laporan keuangan. Tingkat pengyimpangan yang meningkat yang dilakukan oleh aparat pemerintah akan mengurangi tingkat pengungkapan laparan keuangan. Hal ini dikarenakan aparat pemerintah berusaha menutupi penyimpangan yang mereka lakukan sehingga mengurangi pengungkapan yang harus diketahui atau dilakukan.

Dalam penelitian sebelumnya ada peneliti yang menemukan penelitian yang sama yaitu Listiani (2008) dan Waliyyani dan Mahmud (2015). Yang menyatakan bahwa temuan audit berpenaruh negatif tidak signifikan terhadap tingkat pengungkapan LKPD, namun dari peneliti yang lain tidak mendukung yaitu Ernawti (2016) dan dasn Hilmi (2012) yang menyatakan bahwa temuan audit berpengaruh positif signifikan terhadap tingkat pengungkapan LKPD.

\subsubsection{Pengaruh OPD Terhadap Tingkat Pengungkapan LKPD}

Berdasarkanpengujian yang dilakukan bulan juni 2019 sampai awal juli 2019 pada tabe 4.9 tentang uji t yang menunjukan bahwa OPD H4 ditolak berpengaruh positif tidak signifikan (tidak berpengaruh) terhadap tingkat pengungkapan LKPD. Semkin kompleks sebuah pemerintahan dengan menjalankan kegiatan akan menyebabkan semakin besar tingkat pengungkapan yang dilakukan pemerintah. Peneliti mencoba mengggunakan jumlah OPD sebagai salah satu proksi untuk menjelaskan kompleksitas. Jumlah OPD menggabarkan jumlahurusan yang menjadi prioritas pemerintah daerahdalam membangun daerah. Maka dari penelitian ini peneliti menemukan bahwa sangat kecil tingkat kompleksitas pada sebuah pemerintah daerah dalam menjalankan kegiatan yang menyebabkan semakin rendah tingkat pengungkapan yang di lakukan dalam pemerintah daerah.

Hasil dalam penelitian ini tidak mendukung teori stewardship yang menyatakan bahwa semakin banyak jumlah OPD mka semakin banyak jumlah steward yang akan manjalankan suatu pemerintahan dan memberikan insormasi kepada principal. Alasan yang mendasari peneliiti untuk tidak mendukung 
teori stewardship yaitu dengan banyaknya steward dalam sebuah pemerintahan tidak akan mendorong peningkatan yang memenuhi tingkat pengungkapan LKPD yang lebih baik, karena kegiatan antar OPD cenderung generik, julah OPD yang lebih sedikit dapat mengurangi sifat generik ini sehingga kegiatan OPD mampu di maksimumkan kembali. dengan begitu mungkin bisa mendapatkan dampak pada tingkat pengungkapan yang lebih baik karena dari hasil OPD yang lebih berkualitas.

Hasil penelitian ini sejalan dengan penelitian sebelumnya yaitu Ernawti (2016) dan Suransi(2015) menyatakan bahwa OPD berpengaruh positif tidak signifikan (tidak berpengaruh) terhadap tingkat pengungkapan LKPD. Dan peneliti ini tidak mendukung Khasanah dan Rahardjo (2014) menyatakan penelitian berpengaru negative signifikan terhadap tingkat pengungkapan LKPD.

\subsubsection{Pengaruh Tingkat Ketergantungan Terhadap Tingkat Pengungkapan LKPD}

Berdasarkakn hasil penelitian yang dilakukan bulan juni 2019 sampai awal juli 2019 di uji dalam uji t dan hasil dari penelitian tersebut yabg ada pada tabel 9 menyatakan bahwa $\mathbf{H 5}$ ditolak dan dapat disimpulkan bahwa tingkat ketergantungan berpengaruh positif tidak signifikansi (tidak berpengaruh) terhadap tingkat pengungkapan LKPD. Dalam penelitian ini menjelasksn bahwa dalam tingkat pengungkapan LKPD tidak bergantung pada bsarnya tinkat ketergantungan karena pemerintah pusat kurang memberikan kontrolterhadap penggunaan dana transfer sehingga pemerintah daerah tidak terdororng untuk meningkatkan pengungkapan LKPD. Jika pada saat menentukan anggaran dana transfer disebuah daerah tidak di monitoring, maka tidak akan pernah mendorong pemerintah daearh tersebut untuk meningkatkan pengungkapan kualitas pada laporan keuangan.

Hasil dari penelitian ini tidak dapat mendukung toeri stewardship yang menyatakan bahwa dalam pertangggungjawaban atas setiap penggunaan dana tersebut merupakan upaya dari kesadaran steward dengan menjalani tanggung jawabnya yaitu melalui bentuk transparansi dan akuntabilitas pengelolaan keuangan daerah sekaligus untuk mewujudkan kepercayaan publik baik terhadap masyarakat ataupun pemerintah pusat atau provinsi bahwa dana tersebut agar tidak disalah gunakan.

Hasil penelitian ini sejalan dengan penelitian penelitian sebelumnya yaitu Waliyyani dan Girsang (2015), yang menyatakan bahawa tingkat pengungkapan yang berpengaruh positif tidak signifikan terhadap tingkat pengungkapan LKPD. Dan penelitian ini idak mendukung penelitian Setyaningrim dan syafitri (2012) tingkat ketrgantungan berpengaruh negative sigifikan terhadap tingkat pengungkapan LKPD.

\section{PENUTUP}

\subsection{Kesimpulan}

Penelitian ini mencoba melihat semua faktor-faktor yang mempengaruhi setiap tingkat pengungkapan LKPD tahun 2015-2017. Berdasarkan hasil pengujian dan analisis dalam penelitian ini. Tingkat pengungkapan yang sudah dilakukan oleh pemerintah masih rendah, namun tren tingkat pengungkapan yang dillakukan oleh pemerintah provinsi terus meningkat dari tiga tahun terakhir.

Ukuran Pemerintah Daerah berpengaruh positif tidak signifikansi terhadap tingkat pengungkapan Laporan Keuangan Pemerintah Daerah (LKPD) pada 28 Kabupaten dan 1 Kota di Prvonsi Papua Tiga periode terakhir (2015-2017)

Umur Pemerintah Daerah berpengaruh positif signifikansi terhadap tingkat pengungkapan laporan keuangan pemerintah daerah (LKPD) pada 28 Kabupaten dan 1 Kota di Prvonsi Papua Tiga periode terakhir (2015-2017)

Temuan Audit berpengaruh negatif tidak signifikansi terhadap tingkat pengungkapan laporan keuangan pemerintah daerah (LKPD) pada 28 Kabupaten dan 1 Kota di Prvonsi Papua Tiga periode terakhir (2015-2017)

Jumlah SKPD/OPD berpengaruh positif tidak signifikansi terhadap tingkat pengungkapan laporan keuangan pemerintah daerah (LKPD) pada 28 Kabupaten dan 1 Kota di Prvonsi Papua Tiga 
periode terakhir (2015-2017)

Ketergantungan fiskal berpengaruh positif tidak signifikansi terhadap tingkat pengungkapan laporan keuangan pemerintah daerah (LKPD) pada 28 Kabupaten dan 1 Kota di Prvonsi Papua Tiga periode terakhir (2015-2017)

\subsection{Saran}

Dalam penelitian selanjutnya yang akan diambil mengenai tingkat pegungkapan LKPD harus menjadi hal sangat yang penting untuk dapat dikembangkan dan juga diteliti lebih jauh lagi karena masih sangat jarang dilakukan . Dengan mempertimbangkan setiap hasil yang telah diperoleh dalam penelian ini, maka peneliti sangat menyarankan hal-hal sebagai berikut .Untuk penelitian selanjutnya sangat diharapkan agar dapat menambahkan variabel penelitian yang diduga memiliki pengaruh yang sangat besar terhadap setiap tingkat pengukapan LKPD yang ada di Kabupaten/Kota yang ada di Provinsi Papua.Untuk penelitian selanjutnya sangat diharapkan dapat mengunakan setiap data LKPD yang terbaru dan periode waktu yang lebih panjang sehinga akan lebih kelihatan semua perkembangan tingkat pengungkapan LKPD terutama di Kabupaten/Kota yang ada di Provinsi Papua. 


\section{DAFTAR PUSTAKA}

Adisa smita, Rahardjo. (2010). Manajemen Pemerintah Daerah. Makasar: Graha Ilmu.

Basuki. (2007). Pengelolaan Keuangan Daerah. Yogyakarta: Kreasi Wacana. Government Accounting Disclosure', Journal of Accounting and Public Policy, vol. 11, issue 1, spring, pp. 142

Fadzil, Faudziah Hanim, dan Nyoto, Harryanto. (2011). Fiscal Decentralization after Implementation of Local Government Autonomy in Indonesia. World Review of Business Research Vol 1 No, 2 pp 51-70.

Ikhtisar Hasil Pemeriksaan Semester I Tahun 2010. (2010). Jakarta: Badan Pemeriksa Keuangan Republik Indonesia (BPK RI).

Gore, Angela K 2004, 'The Effects of GAAP regulation and bond market interaction on Local Government Disclosure', Journal of Accounting and Public Policy, vol.23, issue, 1,JanFeb,pp.23-52.

Giroux, Gary dan Andrew J. McLelland, 2003, 'Governance Structures and Accounting at Large Municipalities', Journal of Accounting and Public Policy, 22, pp. 203-230.

Halim, Abdul, dan Abdullah, Syukriy. (2006). Hubungan dan Masalah Keagenan di Pemerintah Daeah (Sebuah Peluang Penelitian Anggaran dan Akuntansi). Jurnal Akuntansi Pemerintahan Vol. 2 No. 1 pp 53-64.

Peraturan Mendagri No. 13 Tahun 2006 tentang Pedoman Pengelolaan Keuangan Daerah.

Peraturan Pemerintah No. 105 Tahun 2000 tentang Pengelolaan dan Pertanggungjawaban Keuangan Daerah.

Peraturan Pemerintah No. 24 tahun 2005 tentang Standar Akuntansi Pemerintah. Undang-Undang No 17 Tahun 2003 tentang Keuangan Negara.

Undang-Undang Nomor 22 Tahun 1999 tentang Pemerintah Daerah

Undang-Undang No. 32 Tahun 2004 tentang Pemerintah Daerah 